\title{
Numerical modelling of underground and open pit interaction in a gold mine
}

\author{
K He PSM, Australia \\ G Swarbrick PSM, Australia \\ TD Sullivan PSM, Australia
}

\begin{abstract}
The Waihi Gold operation (OceanaGold) consists of a mining and milling complex located within the township of Waihi, approximately $125 \mathrm{~km}$ southeast of Auckland, New Zealand. Mining at Waihi started in 1878 and comprised both underground mining (1878 to 1952) and open cut mining (1988 to present). The Martha Mine and its immediate environs have experienced a very long period of deformation and subsidence due to the historical underground mining. This study contains an assessment of the potential impacts of the proposed Martha Underground mine on the stability of proposed Martha Phase 4 pit. A 3D numerical model is developed by considering both historical and proposed underground and open cut mining. Caving affected rock mass zones around a planned historical underground caving operation, which has been incorporated into the model. The developed 3D model predicts a response to Martha Underground that is aligned with the experience and previous performance of the Martha Pits in terms of magnitude, location and distribution of movements. Sensitivity analyses were undertaken to investigate the effect of several input parameters used in the study.
\end{abstract}

Keywords: underground mining, open cut mining, caving zones, numerical modelling

\section{Introduction}

\section{$1.1 \quad$ General}

The Waihi Gold operation (OceanaGold) consists of a mineral and mining complex located within the township of Waihi, approximately $125 \mathrm{~km}$ southeast of Auckland, New Zealand. Gold was first discovered in Martha in 1878 and was mined by underground method between 1882 and 1952 . The Martha open pit operation (Martha Pit) began in 1988, mining remnant material adjacent to historical mining areas and backfill material (of ore grade) from historical cut-and-fill workings. The pit began in 1988 as the Licenced Pit, progressing to the Extended Pit, the South Stability Cutback and the East Layback; before the pit was closed temporarily in 2015 due to failure of the north wall. The underground workings comprise a number of mineralised veins termed lodes, of which the main ones are the Martha, Empire, Royal and Albert and Welcome lodes. Workings within these lodes are commonly referred to as the 'Martha Workings' etc. Detailed records are available for the period of open cut mining (approaching 30 years), while there are limited records of varying quality are available for the 70 year period of underground mining.

OceanaGold is proposing to cut back the north wall failure and complete the East layback pit at depth. Figure 1 shows Martha Phase 4 pit, and the planned underground mining for Martha Underground. Martha Phase 4 pit will be mined in a single top down sequence. Ore and waste will be mined by conventional drill and blast methods. The planned work will take around nine years to complete.

Mining of the new Martha Underground mine commenced in July 2019 with the initial development of declines to connect the two existing exploration drives that were established over the last two years. 

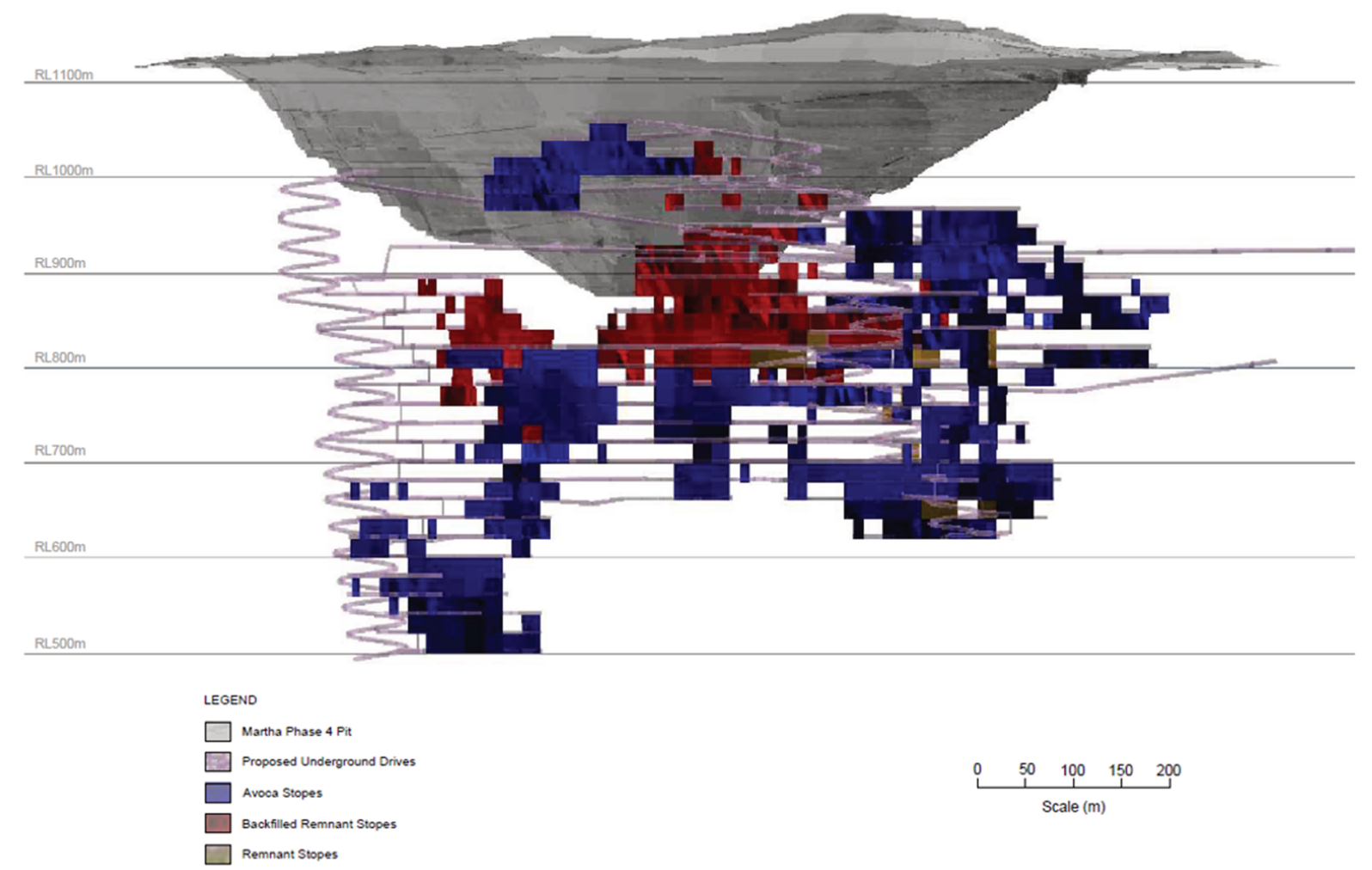

Figure 1 Proposed Martha Phase 4 pit and Martha Underground

The main objective of this study is to assess the potential impacts of the Martha Underground mine on Martha Phase 4 pit and surrounding areas. The analysis includes the latest data describing topography, lithology, historical underground and open cut mining, proposed underground and open cut mining. Other inputs include the compressibility and the strength of the rock mass, the mining sequence, the influence of stope backfill, and in situ stress regime. The sensitivity of material parameters and assumptions adopted in this assessment were tested using a number of cases.

The focus for the analyses was on assessing:

- The magnitude and distribution of displacements due to Martha Underground development.

- The potential for localised failure of the rock mass.

- The degree of interaction between existing underground workings, Martha Underground and Martha Phase 4 pit.

- The sensitivity of the results to changes in parameters or assumptions.

Pells Sullivan Meynink Pty Ltd (PSM) has been providing advice and slope design for the Waihi Operations since 1985 and that experience forms the basis of the understanding of the geotechnical behaviour of Martha Pit. These assessments (PSM 2003, 2005a, 2005b, 2006, 2009a, 2009b) include important information on data, testing, geotechnical drilling, rock mass logging, geotechnical parameters and studies carried out to evaluate the zones of the rock mass adversely affected by underground mining.

\subsection{Geology and groundwater}

Waihi gold mineralisation is mainly contained in quartz veins within a low sulphidation epithermal vein system hosted by Miocene calc-alkaline volcanics of the Coromandel Volcanic Zone. Locally this host rock is termed Andesite. The main east-northeast trending veins are (from north to south): Martha, Welcome, Empire and Royal. The Martha dips steeply south while the other veins dip steeply north. The Albert and 
Edward Lodes trend north. Numerous smaller veins and veinlets between the major lodes also contain gold. Ore grade mineralisation extends for 1,600 metres along strike with a width of 500 metres and was mined to 600 metres below surface.

After erosion of some hundreds of metres of the hydrothermal system, the andesite formed a fossil hill with a thin layer of eluvial and alluvial deposits. Subsequently, the hill and its surrounds were covered with a sheet of ignimbrite to $50 \mathrm{~m}$ thickness. In turn, the hill was eroded from the top of Martha Hill, leaving a window of andesitic outcrop containing the vein system, surrounded by ignimbrites on three sides. A blanket of geologically recent rhyolitic ash to $4 \mathrm{~m}$ thickness covers another layer of eluvial quartz over ignimbrite.

The latest stratigraphic column for the Waihi area describes three main geological units within the pit:

- Andesite: this is a variably jointed, high strength rock with a surficial layer of variable weathering/alteration and a zone of deep oxidation along the main lode. This unit contains the gold mineralisation. In local areas of the pit, the andesite is extensively clay-altered in which rock clasts are contained by and within a soft clay matrix, forming a low strength soil mass.

- Younger (contact) andesite, also termed the Younger Andesite or the 'Blue Shear': this unit immediately overlies and is distinguishable from the main andesite as a low to high strength, blue grey coloured, variably sheared and variably clay-altered rock.

- Ignimbrite Zone: this forms the more recent overburden overlying the mineralised andesite host rocks. It is thickest in the east-southeast but also extends into the west of the pit. The Ignimbrite Zone includes a range of material types including welded and unwelded ignimbrites, tuff, alluvium, and recent brown ash. The welded ignimbrite is a relatively high strength rock while the other units exhibit a range of engineering strengths. Minor amounts of non-engineered fill overlie the Ignimbrite Zone.

The Martha Pit is intersected by a relatively minor number of geological faults, the majority of which exhibit parallel trends to the mineralisation zones and are steeply inclined. These faults have had minimal influence on pit stability over the last 20 years of open pit mining. The exception to this was the north wall failure, which occurred partly along a structure dipping to the south.

A review of all historical and current operational piezometers has been carried out for this study. While most of the piezometers located within the East Layback have been decommissioned due to pit development, the surrounding operational piezometers indicate that the groundwater regime has not changed significantly in the last few years. The data shows underdrainage by the Andesite is a universal condition throughout the region. To the south, east and southwest groundwater levels in the Andesite have continued to fall and follow the pit dewatering. There are no indications of seepage on these walls. In the north there are limited underground workings, the groundwater levels in Andesite have stabilised, also show underdrainage and are well behind the pit face. Therefore, the groundwater pressure is not considered in the analyses reported in this study.

\subsection{Historical underground mining impacts}

Mining at Waihi started in 1878 and comprised two main phases:

- Underground mining, 1878 to 1952.

- Open cut mining 1988 to present.

The Martha Mine and it immediate environs have experienced a very long period of deformation and subsidence due to the historical underground mining. The classic model for deformations of the rock mass around a planned underground caving operation entails three more or less concentric zones:

- Caved zone: A central zone comprising a completely broken rock mass, with particle sizes ranging from very large blocks to silt size. 
- Disturbed Zone: A zone adjacent to and partially around the central zone comprising a disturbed rock mass, possibly with block sliding on shears, opening and weathering of joints, noticeably increased fracturing and minor local caved zones. In places the intact rock appears altered or weathered.

- Deformed Zone: An outer zone surrounding the inner two zones within which there have been smaller displacements. The rock appears intact, but there is noticeable staining of rock substance and defects; together with an increase in fracturing compared to fresh intact rock at depth.

In simple terms, the overall underground system at Waihi can be conceptualised in terms of this classic model, with the exception that because of geometry and layout of the underground workings the zones are skewed towards the south, southeast and east. The Disturbed and Deformed Zones were thought to be poorly developed in the north. However, the North Wall Failure has shown this is not the case and that the northeast area lies within the Disturbed Zone. There is no evidence of any of these Zones in the west and northwest of the pit. Further to the east where the more recent volcanic layers (Ignimbrite Zone) overlies the Andesite these zones are masked.

Historical records indicate that caving around the Milking Cow region first occurred accidentally due to loss of ground control during mining. Thereafter intentional caving of selected areas of the Martha Lode was carried out. In addition, due to historical re-mining, other large-scale collapses of other stopes also occurred during early underground mining. In summary the underground deformation model as it is currently understood comprises the following elements:

- Widespread but small magnitude subsidence over caved zones.

- Creep movement of large blocks of deformed and disturbed rock masses.

- Block subsidence or settlement, with some block rotation.

- Local chimney development leading to sinkhole collapse formation at the surface.

\section{Methodology}

\subsection{Geometry and mesh}

The numerical analysis of the mechanical model was carried out using the commercial software FLAC3D version 6.00 by Itasca Consulting Group, Inc. (2019). The geometry of the numerical model and the north-south section cut through the model are shown in Figure 2. This region represents a block of ground $2,000 \mathrm{~m}$ wide and $1,500 \mathrm{~m}$ long in plan and varying in thickness from 710 to $730 \mathrm{~m}$. The examples of the pits and stopes are shown in Figures 3 and 4.

Unit and pit geometries for the numerical model were developed using the following procedure:

1. Extrapolation and partial smoothing of the unit boundary and topographic surfaces provided.

2. Repair, interpolation and smoothing of pit shells provided to remove geometric anomalies and facilitate integration with unit boundaries.

3. Intersection of boundary surfaces and interpolated pit shells to form a solid block model.

Generally interpolated surfaces closely match the surfaces provided. However, some modifications were required to facilitate meshing and consequently some areas of the pit are slightly different to design in some locations. The maximum variation is around 5 to $10 \mathrm{~m}$.

Stopes and cave affected zones were identified using the following procedure:

1. Input the geometry surfaces of stopes and cave affected zones based on mine design wire frames.

2. Subdivide and densify elements selected by their proximity to the design or historical surfaces.

3. Group the elements inside and within a specified distance of the design or historical surfaces. 
This approach is commonly adopted to approximate the material property changes on a very irregular boundary, when exact conformation to the surface is not critical. In this case exact matching was not considered critical because it was assessed this would not affect the predicted performance of the Martha Phase 4 pit or surrounding areas, which is one focus of this study.

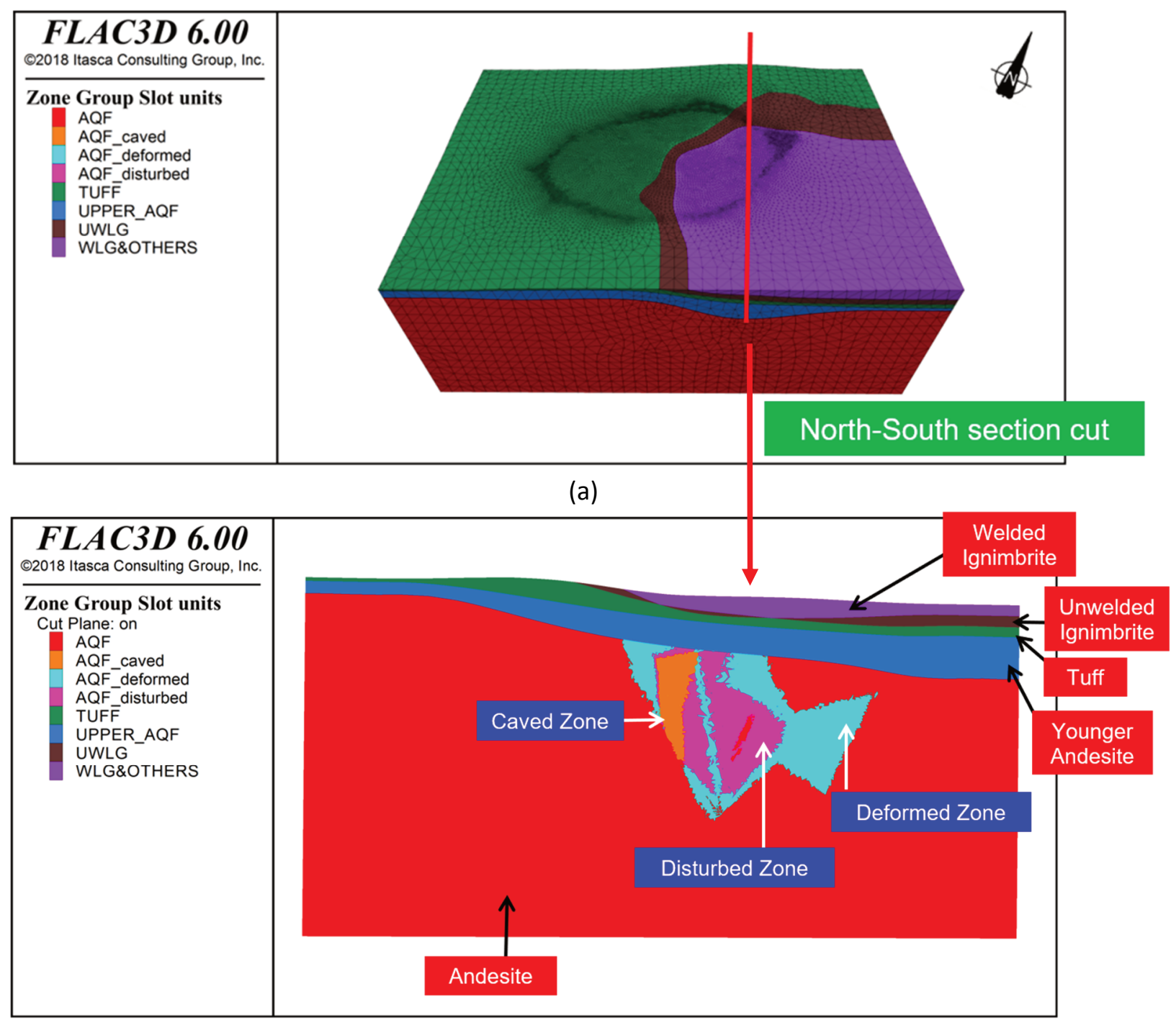

(b)

Figure 2 3D numerical model geometry and mesh: (a) Whole model; (b) North-South section 


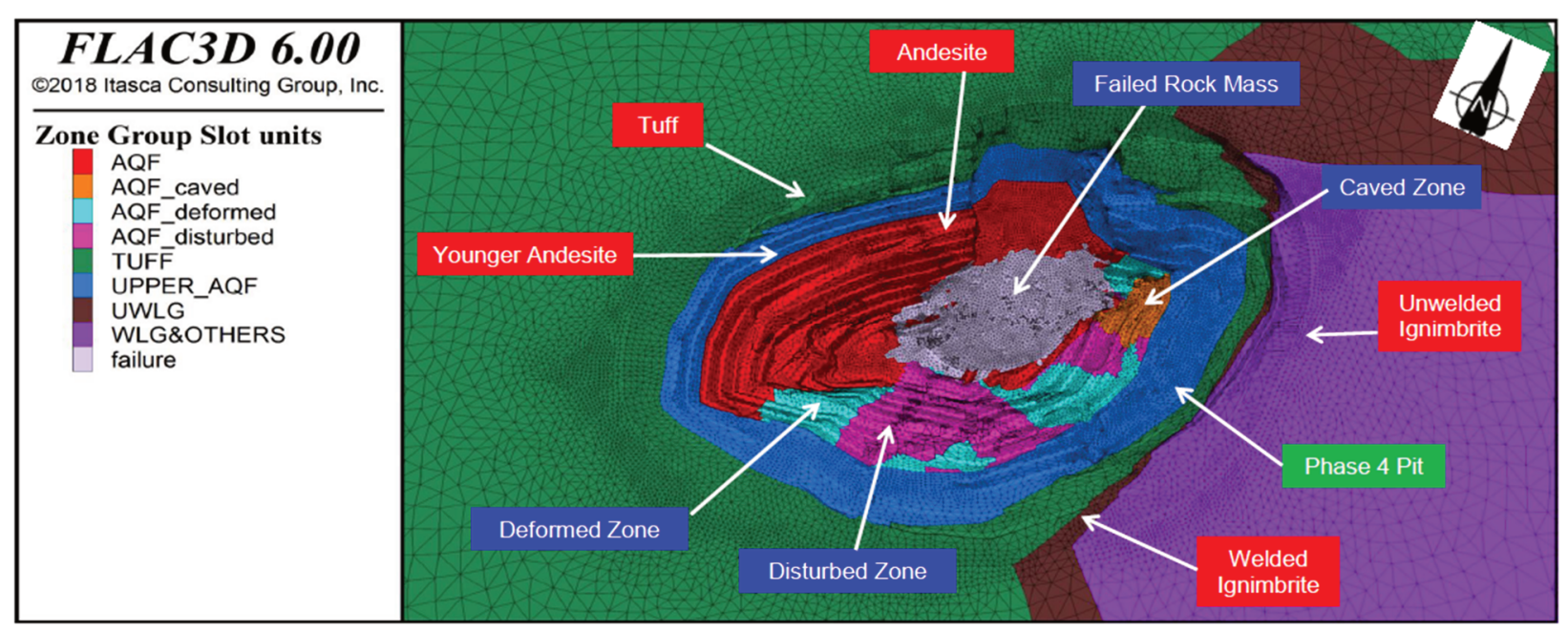

(a)

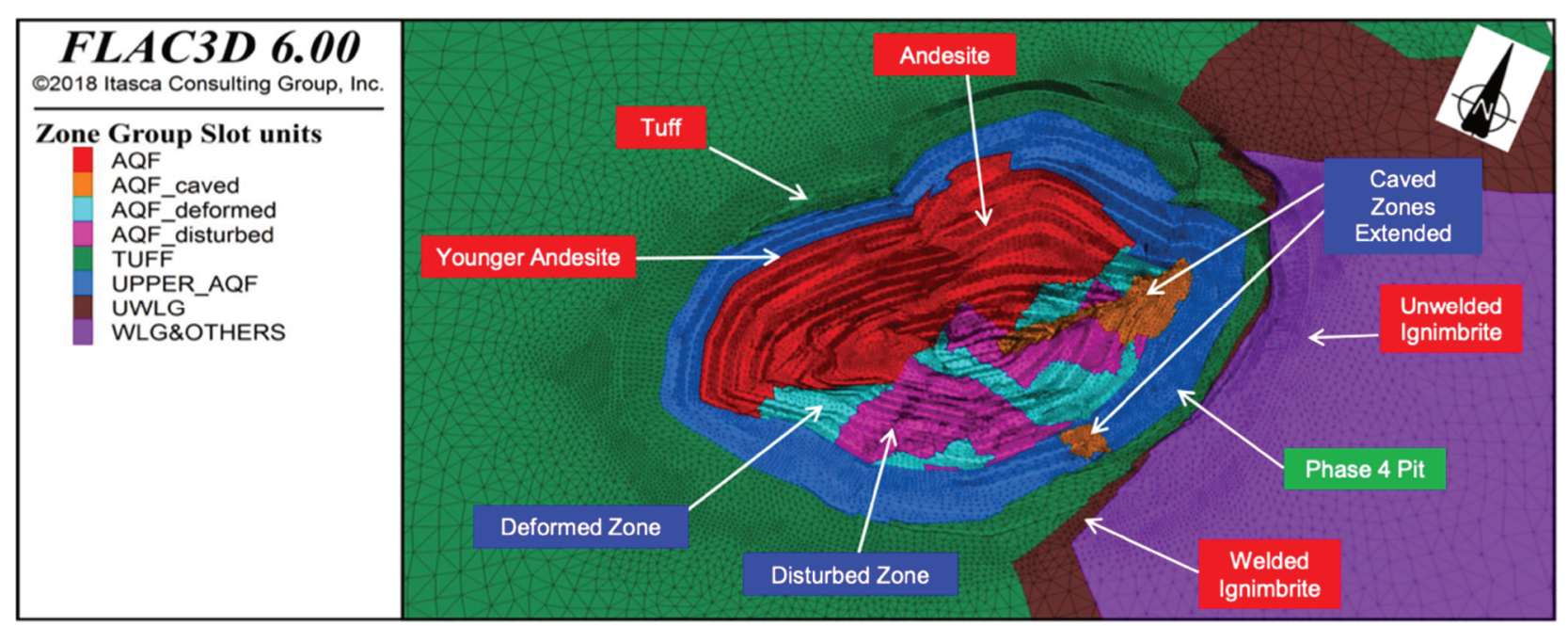

(b)

Figure 3 3D numerical model geometry and mesh: (a) Existing pit; (b) Proposed pit (Martha Phase 4 Pit)

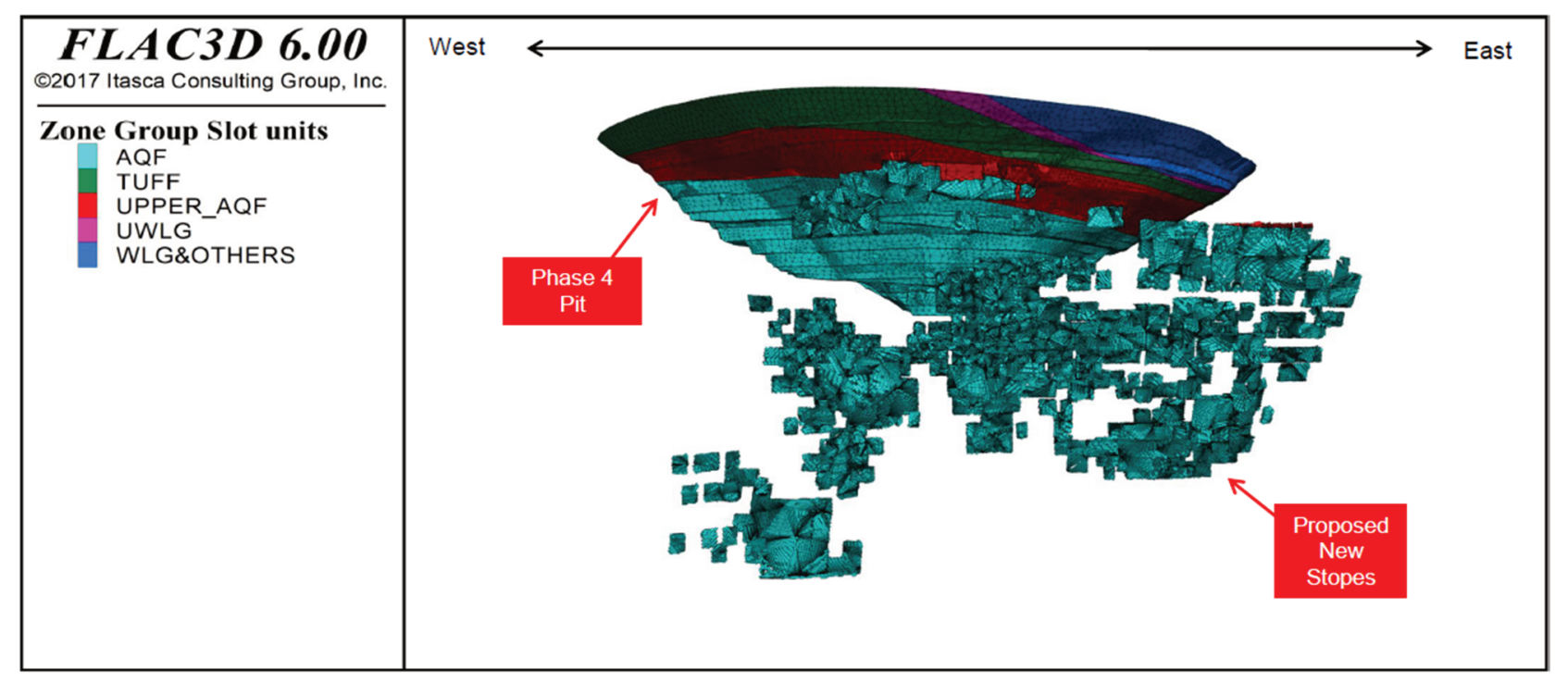

Figure 4 3D numerical model geometry and mesh - proposed stopes (Martha Underground) 
The method used to model stope geometries means that there will be some geometric differences between the numerical model and design. The numerical model is generally geared to be conservative by capturing a greater volume than the design in order to ensure the predictions are conservative. Comparisons of the volumes of the modelled stopes with the design volume, provides a means of quantifying the degree of conservatism. This comparison is shown in Table 1.

Table $1 \quad$ Comparison of stope design and model volumes

\begin{tabular}{|c|c|c|c|}
\hline Stopes & $\begin{array}{l}\text { Volumes estimated } \\
\text { from design }\left(\mathrm{m}^{3}\right)\end{array}$ & $\begin{array}{l}\% \text { of total design } \\
\text { volume of stopes }\end{array}$ & $\begin{array}{l}\text { Volume modelled } \\
\text { ( } \mathrm{m}^{3} \text { and } \% \text { difference } \\
\text { compared with design) }\end{array}$ \\
\hline Proposed new stopes & $1,722,097$ & $54 \%$ & $\begin{array}{l}1,779,271 \\
(103 \%)\end{array}$ \\
\hline Historical unfilled stopes & $1,012,899$ & $31 \%$ & $\begin{array}{l}1,519,550 \\
(150 \%)\end{array}$ \\
\hline Historical filled stopes & 482,719 & $15 \%$ & $\begin{array}{l}729,889 \\
(151 \%)\end{array}$ \\
\hline Total volume & $3,217,715$ & $100 \%$ & $\begin{array}{l}4,028,710 \\
(125 \%)\end{array}$ \\
\hline
\end{tabular}

The model mesh adopted used increasing element sizes from about 1 and $5 \mathrm{~m}$ in the vicinity of the stopes and open pits to around $30 \mathrm{~m}$ at the model boundaries. This resulted in a total mesh density of about 3.4 million elements for the model. This mesh density allowed a multitude of model and sensitivity runs without unduly penalising the accuracy.

\subsection{Material properties and in situ stress}

Geological and geotechnical conditions for the 3D numerical model are based on previous studies carried out by PSM. The main geotechnical units included in the numerical model are:

- Welded ignimbrite.

- Unwelded sandy ignimbrite.

- Tuff.

- Younger andesite.

- Andesite.

Rock mass properties for all units are shown in Table 2. They are modelled as elastoplastic with Mohr-Coulomb yield criterion. The unit weight, Young's modulus, Poisson's ratios, cohesion and friction angle of the rock units are taken from PSM's previous analysis report (PSM 2006). These softened strengths were derived from back-analysis of the two east wall failures and then checked against residual strengths from multi-stage shear box testing of intact material. The tensile strengths of the rock units are calculated based on the assumption of tensile strength/cohesion ratio of 0.25 . The parameters used for the caving affected zones are tested with the monitored movements, and the detailed analyses are not included in this paper.

The backfill material properties used for the stopes are shown in Table 3. The properties for stiff silty clay and loose rockfill were based on PSM experience. The properties for cemented aggregate rockfill (CAF) were based on published research and advice from AMC Consultants Pty Ltd. (AMC 2007). Stope voids were modelled as a highly compressible elastic material rather than a true open void to avoid numerical instability and prevent over closure of the stope walls. 
Table 2 Material parameters for material units

\begin{tabular}{lllllll}
\hline Unit & $\begin{array}{l}\text { Unit weight } \\
\left(\mathbf{k N} / \mathbf{m}^{3}\right)\end{array}$ & $\begin{array}{l}\text { Young's } \\
\text { modulus } \\
(\mathbf{M P a})\end{array}$ & $\begin{array}{l}\text { Poisson's } \\
\text { ratio }\end{array}$ & $\begin{array}{l}\text { Strength } \\
\text { Cohesion } \\
(\mathbf{k P a})\end{array}$ & $\begin{array}{l}\text { Friction } \\
\text { angle } \mathbf{(}^{\circ} \mathbf{)}\end{array}$ & $\begin{array}{l}\text { Tensile } \\
(\mathbf{k P a})\end{array}$ \\
\hline Welded ignimbrite & 25 & 8,000 & 0.2 & 330 & 60 & 82.5 \\
Unwelded ignimbrite & 21 & 1,000 & 0.2 & 35 & 30 & 8.75 \\
Tuff & 17 & 1,000 & 0.25 & 20 & 40 & 5 \\
Younger andesite & 20 & 700 & 0.2 & 40 & 25 & 10 \\
Andesite - undisturbed & 27 & 8,700 & 0.2 & 400 & 65 & 100 \\
Andesite- deformed & 26 & 5,800 & 0.2 & 70 & 40 & 17.5 \\
Andesite - disturbed & 26 & 2,200 & 0.2 & 50 & 40 & 12.5 \\
Andesite- caved & 22 & 600 & 0.2 & 5 & 35 & 1.25 \\
\hline
\end{tabular}

Table 3 Material parameters for stope backfill materials

\begin{tabular}{llll}
\hline Backfill materials & $\begin{array}{l}\text { Unit weight } \\
\left(\mathbf{k N} / \mathbf{m}^{3}\right)\end{array}$ & $\begin{array}{l}\text { Young's } \\
\text { modulus } \\
\text { (MPa) }\end{array}$ & $\begin{array}{l}\text { Poisson's } \\
\text { ratio }\end{array}$ \\
\hline Historical filled stopes - stiff silty clay & 19 & 30 & 0.3 \\
Proposed new stopes - loose rockfill & 20 & 10 & 0.25 \\
Proposed new stopes - cemented aggregate fill (CAF) & 22 & 200 & 0.25 \\
\hline
\end{tabular}

PSM are not aware of any direct in situ stress measurements at the Martha Pit. Consequently, in situ stress data for the site is limited to acoustic emissions measurements on oriented core by Curtin University of Technology. Because of this uncertainty the in situ stress field was assumed based on the assessment by AMC in the Favona Underground Mine (AMC 2007), the Curtin University of Technology summary findings and published data on regional stress distribution. The two stress regimes were adopted in the modelling based on this information are shown in Table 4. Different runs were carried out to assess the sensitivity of displacements to the change in magnitude of the in situ stress, and the results are not very sensitive to the two stress regimes.

Table 4 Stress regime (AMC 2007)

\begin{tabular}{llll}
\hline \multicolumn{2}{l}{ Regime A (most likely) } & \multicolumn{2}{l}{ Regime B (most adverse) } \\
Magnitude & Direction & Magnitude & Direction \\
\hline S1 $=2.5 \mathrm{~Sv}$ & NE-SW & S1 $=2.5 \mathrm{~Sv}$ & NE-SW \\
$\mathrm{S} 2=1.0 \mathrm{SV}$ & NW-SE & $\mathrm{S} 2=1.5 \mathrm{SV}$ & NW-SE \\
$\mathrm{S} 3=1.0 \mathrm{~Sv}$ & Vertical down & $\mathrm{S} 3=1.0 \mathrm{~Sv}$ & Vertical down \\
\hline
\end{tabular}

Notes: $\mathrm{S} 1$ is the major principal stress, $\mathrm{S} 2$ is the intermediate principal stress, $\mathrm{S} 3$ is the minor principal stress and Sv is the vertical stress. 


\subsection{Staging}

The numerical model was used to predict changes in stress and displacement as a consequence of proposed mining development. Analyses included an initial equilibration step to allow in situ stress to reach equilibrium followed by multiple development stages.

The numerical analysis consisted of the following stages:

- Initialisation of in situ stresses using the pre-mining topography.

- Excavation of the historical underground stopes and pit.

- Placement of backfill in historically filled stopes.

- Simulating the North Wall failure as loose rockfill.

- Staged excavation of the proposed Martha Phase 4 pit.

- Staged mining of Martha Underground in yearly progressions from 2020 (Year 2) to 2027 (Year 9).

The Martha Underground sequence modelled was based on a simplification and interpretation of the planned staging. Yearly stages were deemed sufficient to capture time-dependant stress changes to the assessment level required. An exploded view of underground mining sequence is shown in Figure 5 . It should be noted that Year 1 mainly includes the underground drive development, which is not explicitly simulated in the model.

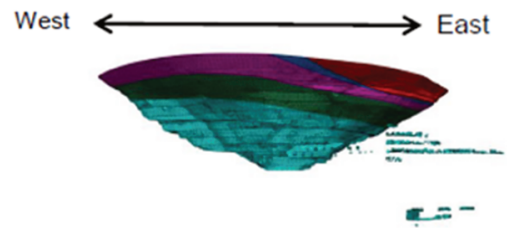

Year 2 Proposed Stopes

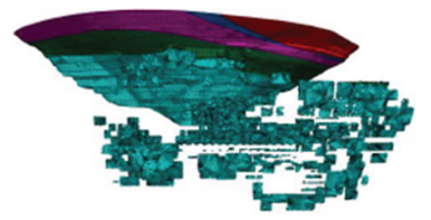

Year 5 Proposed Stopes

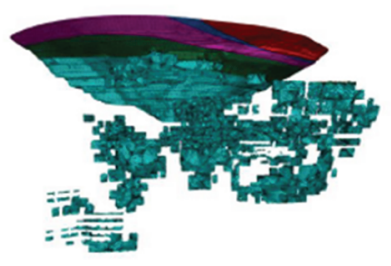

Year 8 Proposed Stopes

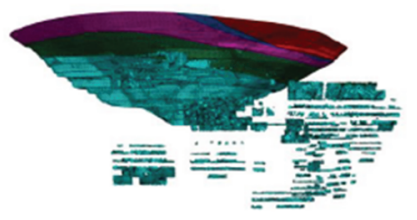

Year 3 Proposed Stopes

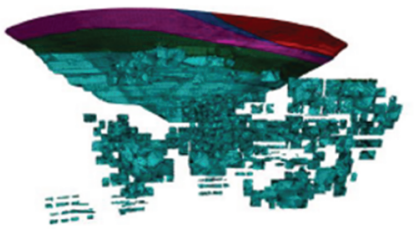

Year 6 Proposed Stopes

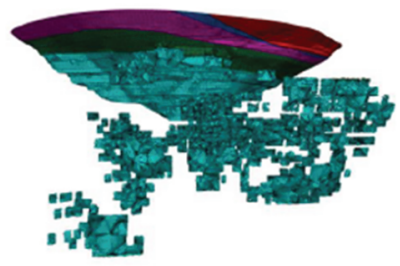

Year 9 Proposed Stopes

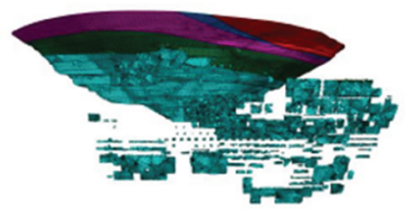

Year 4 Proposed Stopes

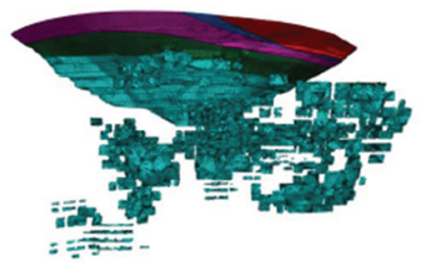

Year 7 Proposed Stopes

Figure 5 Proposed yearly sequence for underground mining 


\subsection{Sensitivity analyses}

Sensitivity analyses were undertaken to bracket the effects of parameters with the least confidence and potentially highest impact. Based on the understanding of the site and previous experience the sensitivity studies focused on:

- Sequencing of the underground workings.

- The presence or absence of backfill for the historical and planed stopes.

- Variation in parameters for the stope backfill materials.

- Changes in magnitude of in situ stress.

- Variations in the volume of the stopes.

- The extent of the caved zones.

Only selected sensitivity analysis results are illustrated in this paper, which are summarised in Table 5.

Table 5 Summary of sensitivity analyses

\begin{tabular}{|c|c|}
\hline Run & Comments \\
\hline Run 1 & $\begin{array}{l}\text { The base case to model planned mining and provide a basis for comparison with other runs: } \\
\text { - Stope backfill material with loose rockfill as shown in Table } 3 . \\
\text { - In situ stress Regime A in Table } 4 \text {. }\end{array}$ \\
\hline Run 2 & $\begin{array}{l}\text { Assessment of backfilling historical unfilled stopes near the pit surface: } \\
\text { - Backfilling historical unfilled stopes } 30 \mathrm{~m} \text { below Martha Phase } 4 \text { pit surface with CAF } \\
\text { before commencing proposed underground workings. }\end{array}$ \\
\hline Run 3 & $\begin{array}{l}\text { Assessment of the sensitivity to stope backfill properties: } \\
\text { - Stope backfill modelled as CAF, Table } 3 \text {. }\end{array}$ \\
\hline
\end{tabular}

\section{$3 \quad$ Results}

The assessment of the modelling results has focused on the predicted displacements and strains. Displacements reflect movement in response to stress change while strains reflect the rate of change of displacement over distance. High strains represent areas where there is a rapid change in displacement over a short distance but not necessarily large displacements overall. Strains, therefore, do not reflect actual instability but highlight areas where material may be over stressed and therefore close to available capacity. Consequently, emphasis has been placed on displacement results as this is a more direct measure of potential pit wall instability and can be compared to the measured data from the existing pit. Given the pit scale and rock mass properties PSM expect that displacements of the order of up to $0.5 \mathrm{~m}$ and strains up to $2 \%$ or less unlikely to result in stabilities larger than bench scale.

Analyses have incorporated several mine sequencing assumptions as some details are not explicitly known at this time. These details include the exact sequence of historical underground mining and which stopes are to be backfilled with CAF under the design allowance of $30 \%$ (30\% of the existing unfilled historical stopes will be stabilised by filling with rockfill). In most cases the assumed model sequence reflects the more adverse impact of global pit wall stability. Sensitivity of these assumptions is tested in other runs, and selected results are discussed in this section.

Run 1 is considered to be the base case for the planned Martha Underground. This run includes several assumptions that produce a relatively conservative prediction of global pit wall stability including loose rockfill material (in Table 3) for stope backfilling everywhere. Figure 6 shows the predicted total displacement 
and maximum shear strain of Year 9 (final stage). The predicted total displacements for Year 9 (final stage) are around $0.2 \mathrm{~m}$ and occur in the east wall, with the maximum occurring in the disturbed zone of the east wall. There are also localised displacements in the historical unfilled stopes at the toe of the north wall. Maximum shear strains on the south wall are predicted to be about $1 \%$ in the deformed zone of the south wall. There are localised strains greater than $1 \%$ predicted in the historical unfilled stopes at the bottom part of the pit. The annual displacements and maximum shear strains developed from Year 2 to Year 9 are shown in Figure 7. The displacements increase steadily during yearly mining sequence and the predicted maximum total displacement in Year 9 (final stage) is about twice the predicted displacement after Year 5. The strains on the south wall start to develop after Year 5.

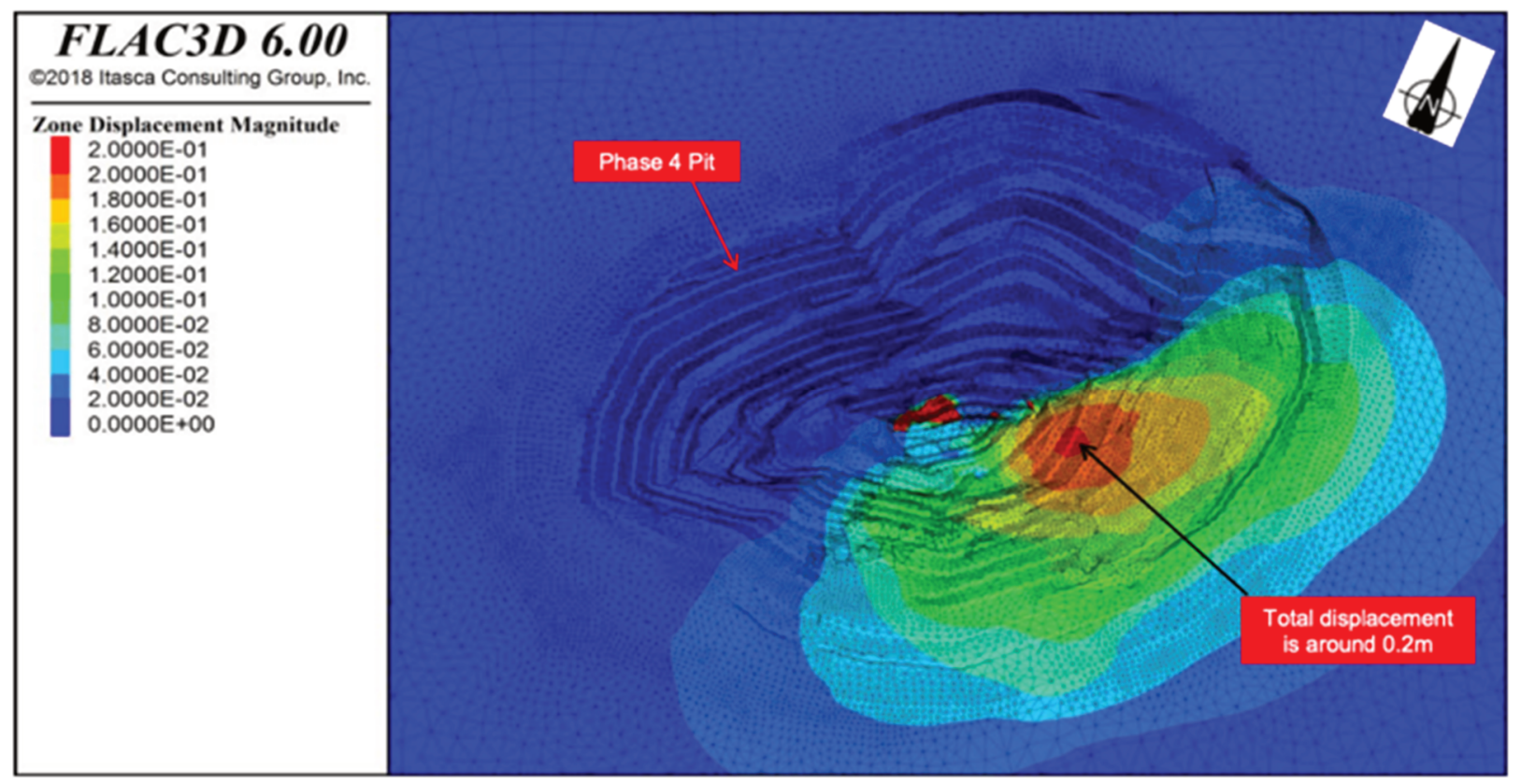

(a)

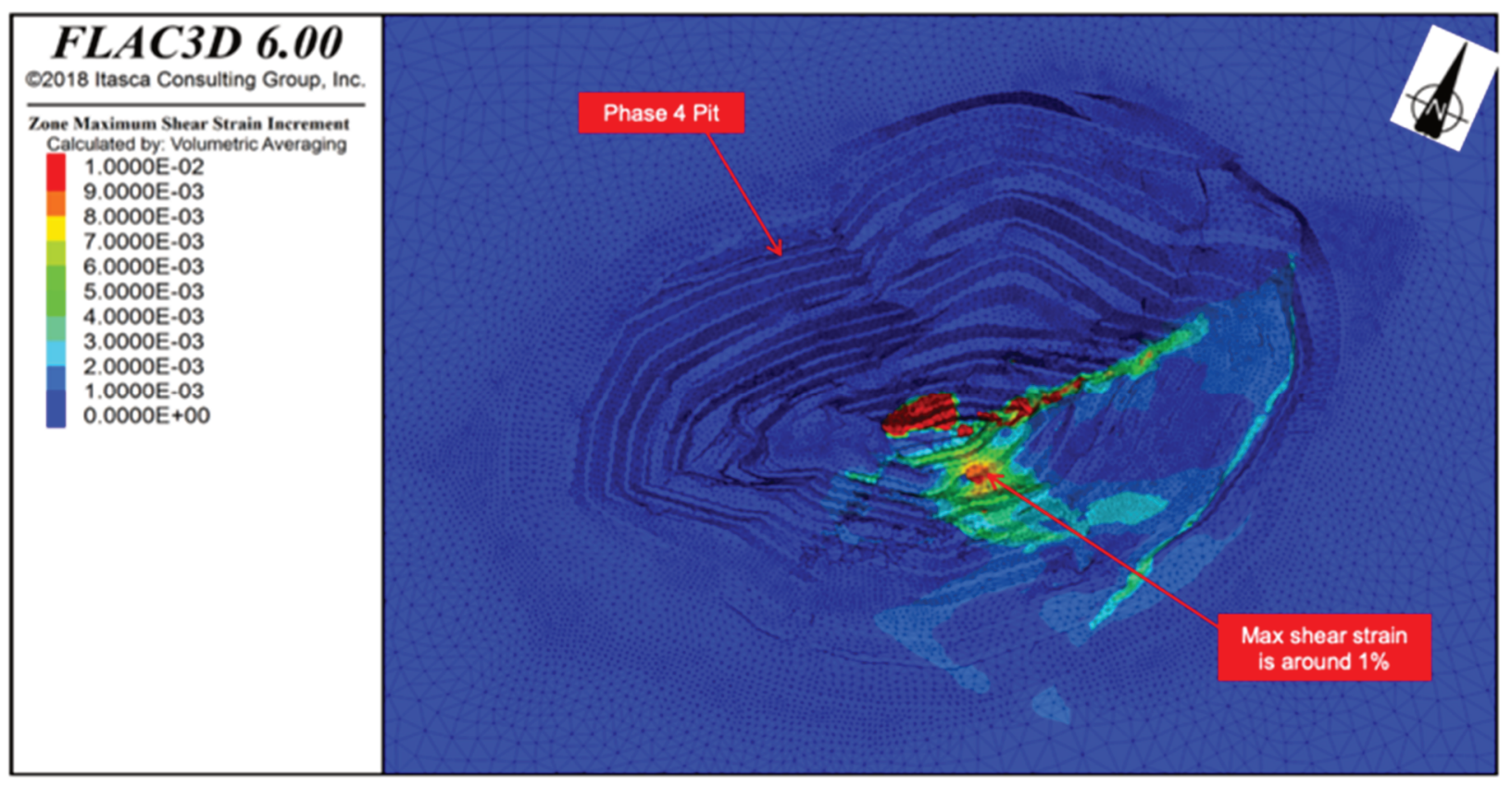

(b)

Figure 6 Predicted total displacement (a), and maximum shear strain (b), after Year 9 - Run 1 


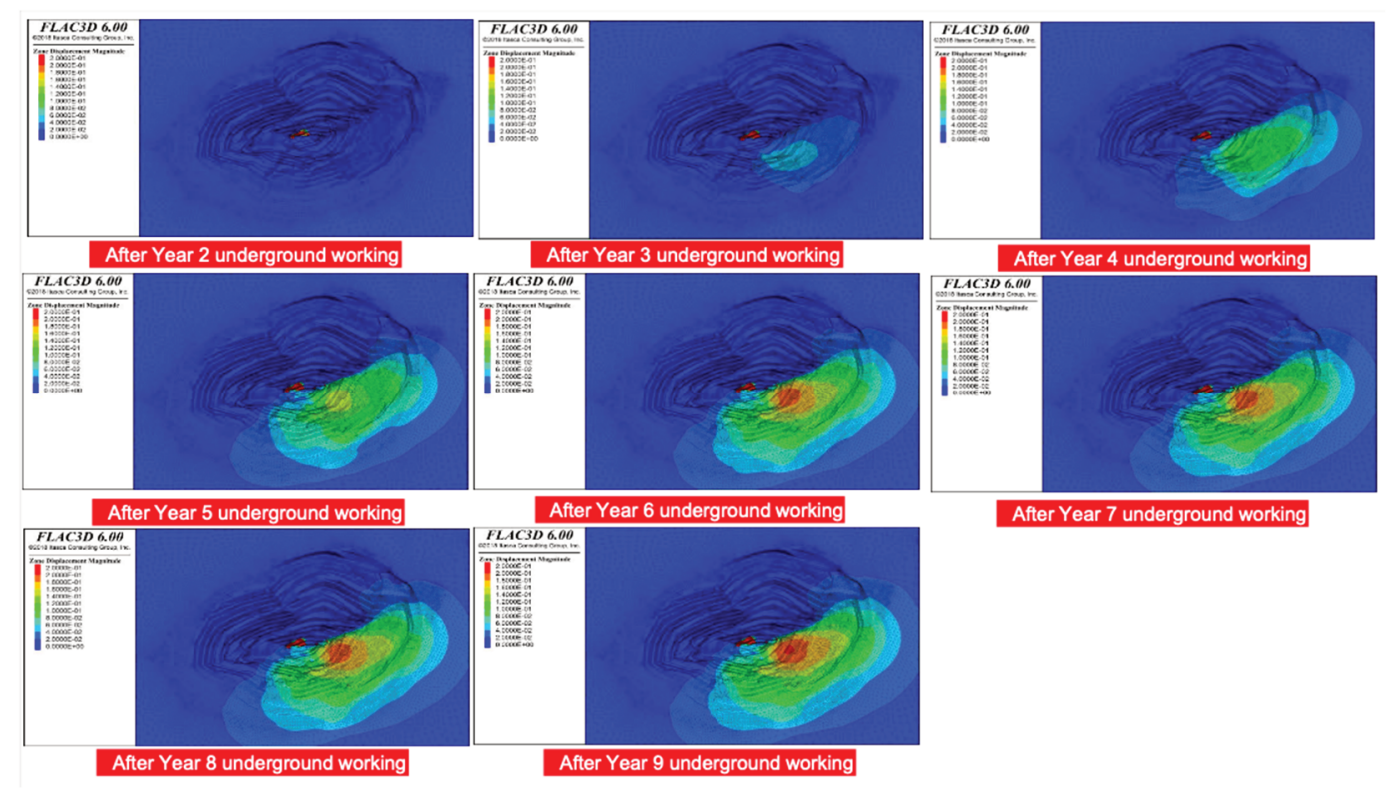

(a)

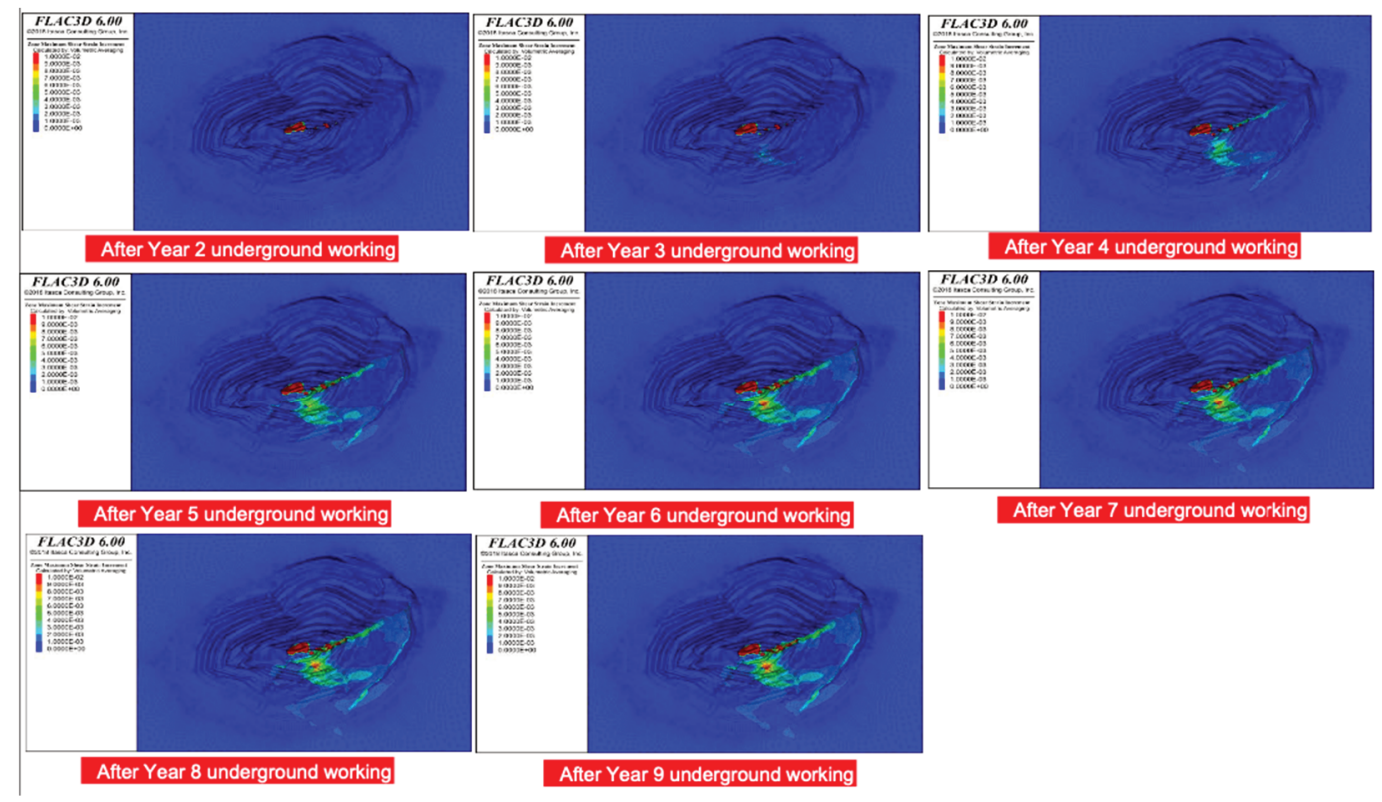

(b)

Figure 7 Predicted total displacements (a), and maximum shear strain (b), for yearly sequence - Run 1

Overall, there is no global slope instability found in Martha Phase 4 pit based on the displacement and strain considering the limits discussed above. There is the potential for localised (bench scale) instabilities at the pit surface in some areas above the historical stoping. From the displacement results, the vertical extent of these localised instabilities is up to $60 \mathrm{~m}$ on the pit surface around the historical unfilled stopes at the bottom of the pit. However, it is expected that the modelled size is overstated as the modelled volume of the historical stopes is greater than design as shown in Table 1. Furthermore, the historical unfilled stopes are modelled as effectively being open by using a highly compressible fill material. This results in relatively high closures and localised strains in historical stopes in the elements close to the stope boundaries. These localised displacements and strains can be reduced by backfilling the historical unfilled stopes, which will be discussed in the following. 
Sensitivity analyses were undertaken to assess the effects of input parameters, and selected results are discussed. The effect of backfilling historical unfilled stopes near the Martha Phase 4 pit surface is simulated in Run 2. In this run, the historical unfilled stopes $30 \mathrm{~m}$ below the Martha Phase 4 pit surface were modelled as backfilled with CAF prior to starting Martha Underground.

The effect of backfilling historical unfilled stopes near the pit surface can be seen by comparing the results between Figures 6 and 8 . This comparison shows that both magnitude and extent of localised displacements and strains at the base of the pit are predicted to be reduced by backfilling the historical unfilled stopes with CAF. The predicted reduction in strain between these cases is around $0.5 \%$. The modelling indicates that backfilling of stopes in the toe of the north wall of Martha Phase 4 would reduce the possibility of local crushing and or pillar/stope stability at the foot of the north wall. However, such backfilling has little to no effect on the overall displacements and strains on the pit walls.

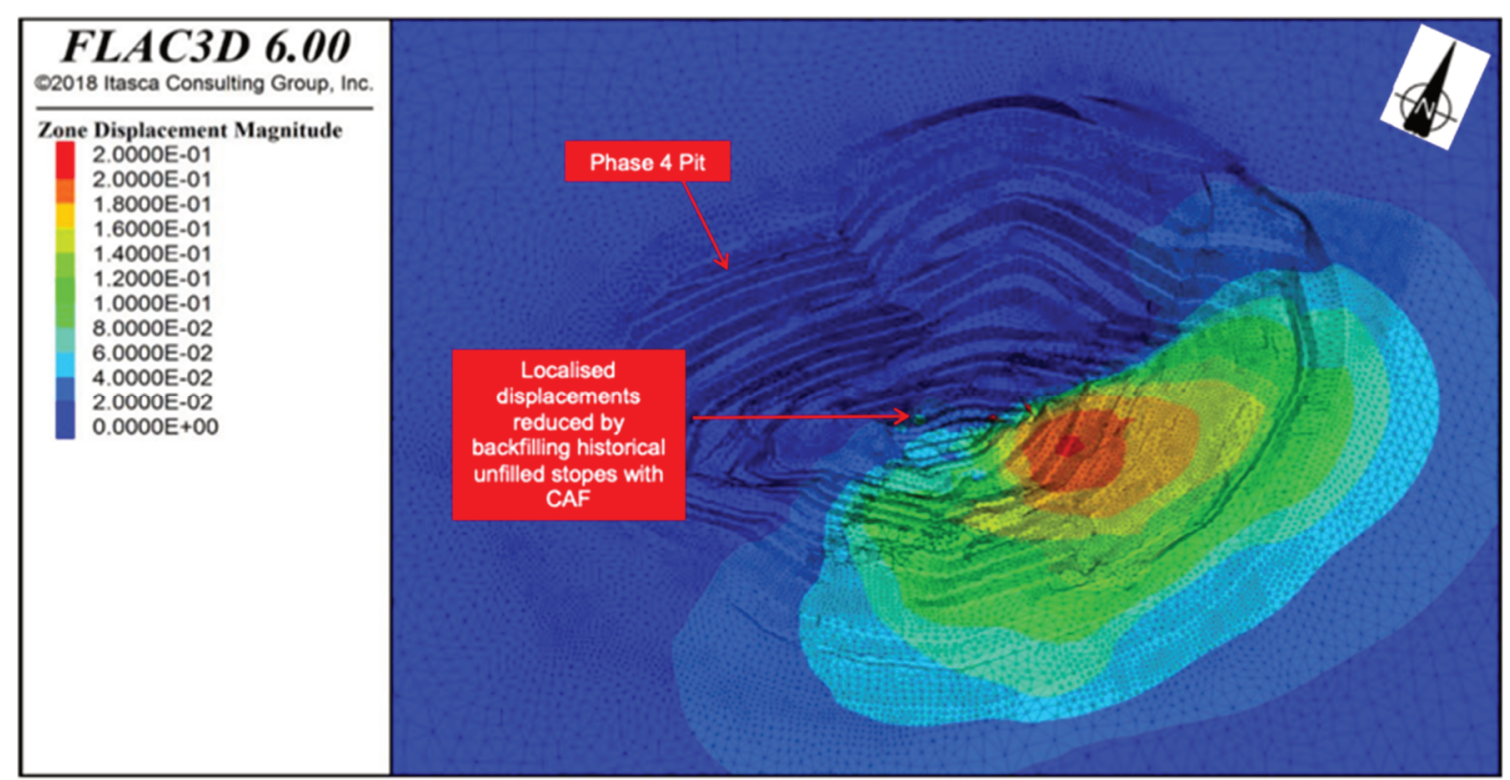

(a)

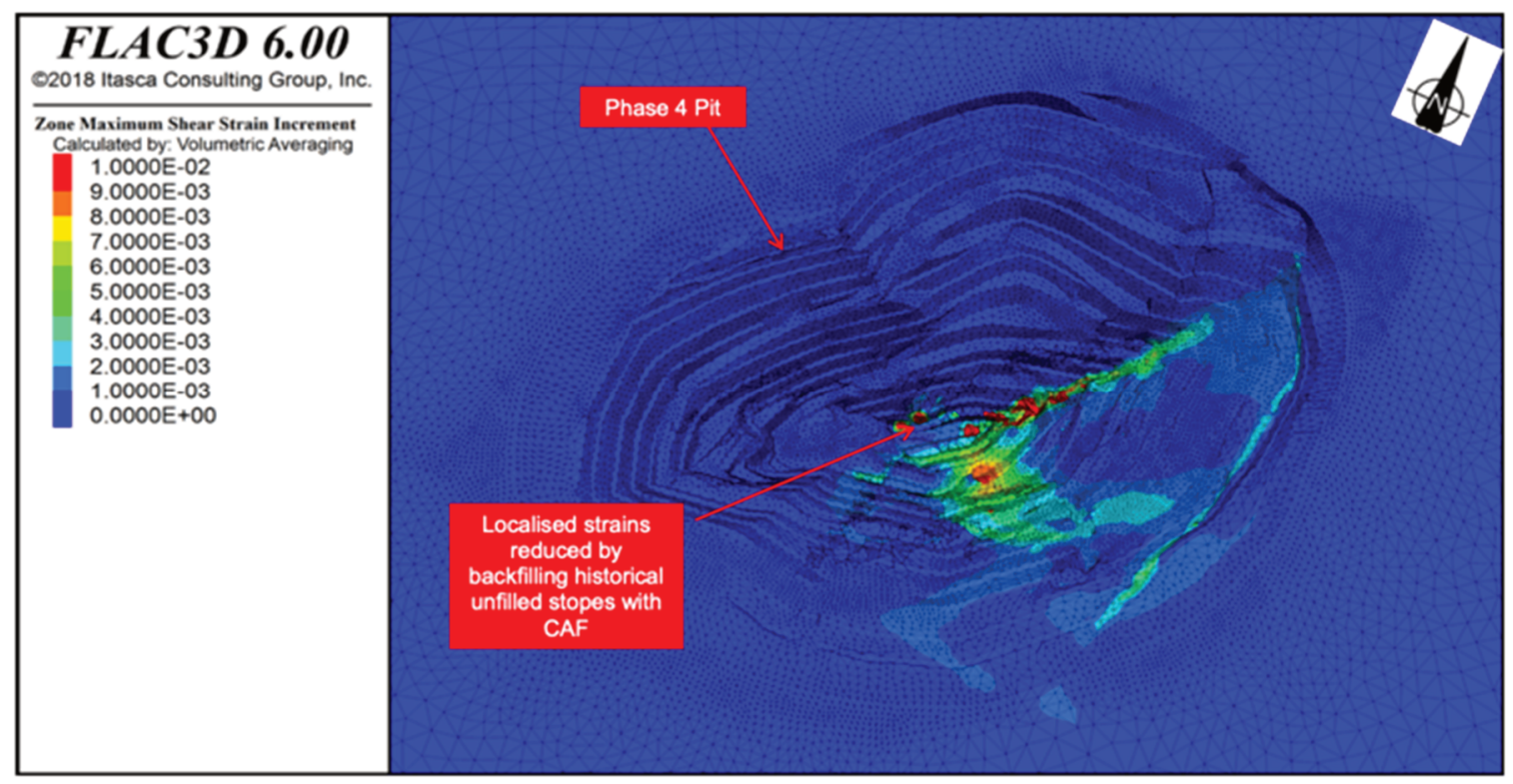

(b)

Figure 8 Predicted total displacment (a), and maximum shear strain (b), after Year 9 - Run 2 
Different sets of properties were used to assess the sensitivity of the results to stope backfill properties, namely stiffness. An elastic compressibility of $10 \mathrm{MPa}$ was used in Run 1 to simulate loose rockfill while $200 \mathrm{MPa}$ was used in Run 3 to simulate CAF. Comparison of the predicted displacements and strains between Run 1 (Figure 6) and Run 3 (Figure 9) indicates that the results are sensitive to the backfill properties. Comparison of the results of Run 1 (loose rockfill) with Run 3 (CAF) shows a reduction in the maximum displacements (from $0.2 \mathrm{~m}$ to $0.08 \mathrm{~m}$ ) and maximum shear strains (from $1 \%$ to $0.2 \%$ ) on the pit wall. Overall a 20 -fold increase in backfill stiffness resulted in a 2.5 -fold reduction in displacement and a 5 -fold reduction in strain.

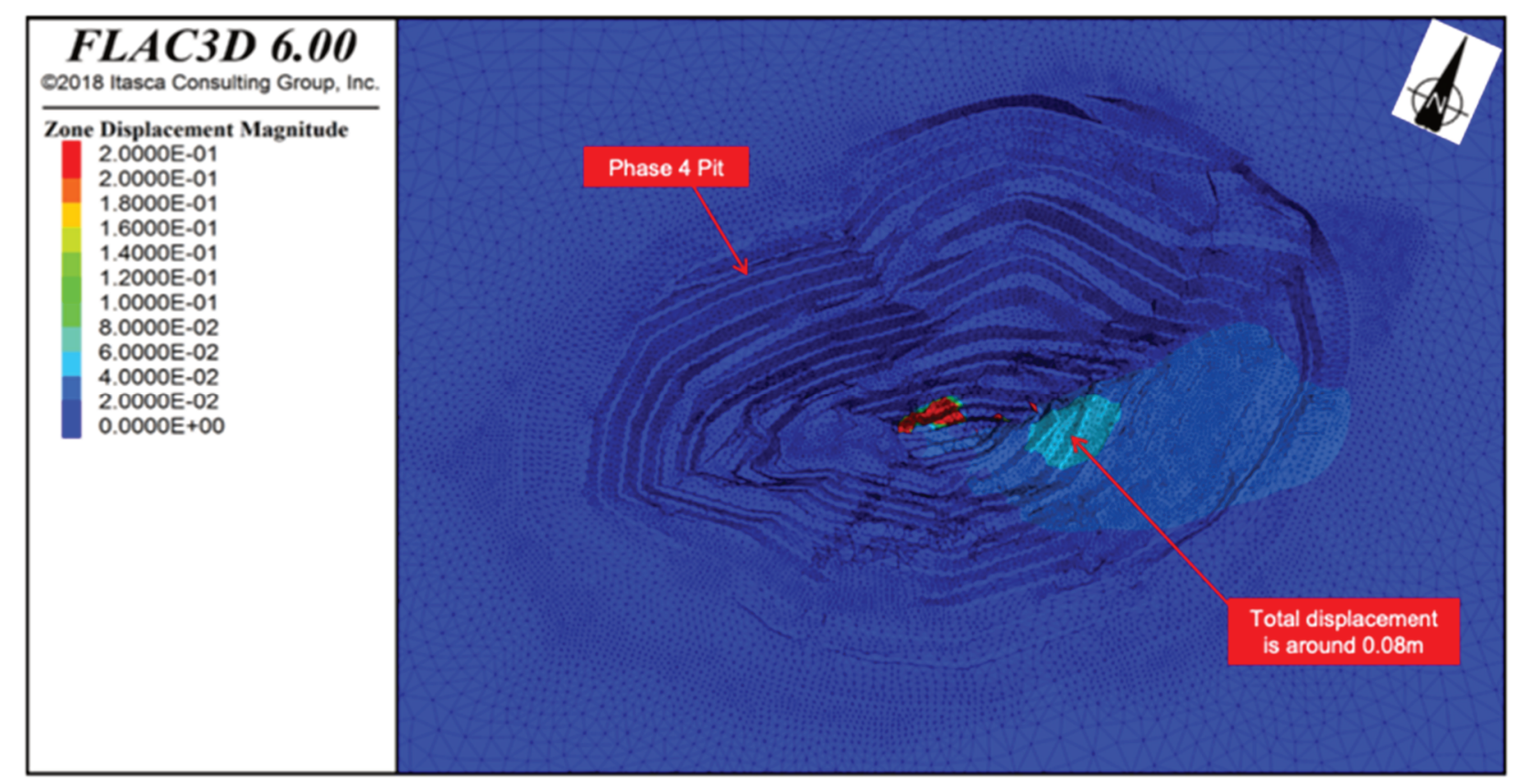

(a)

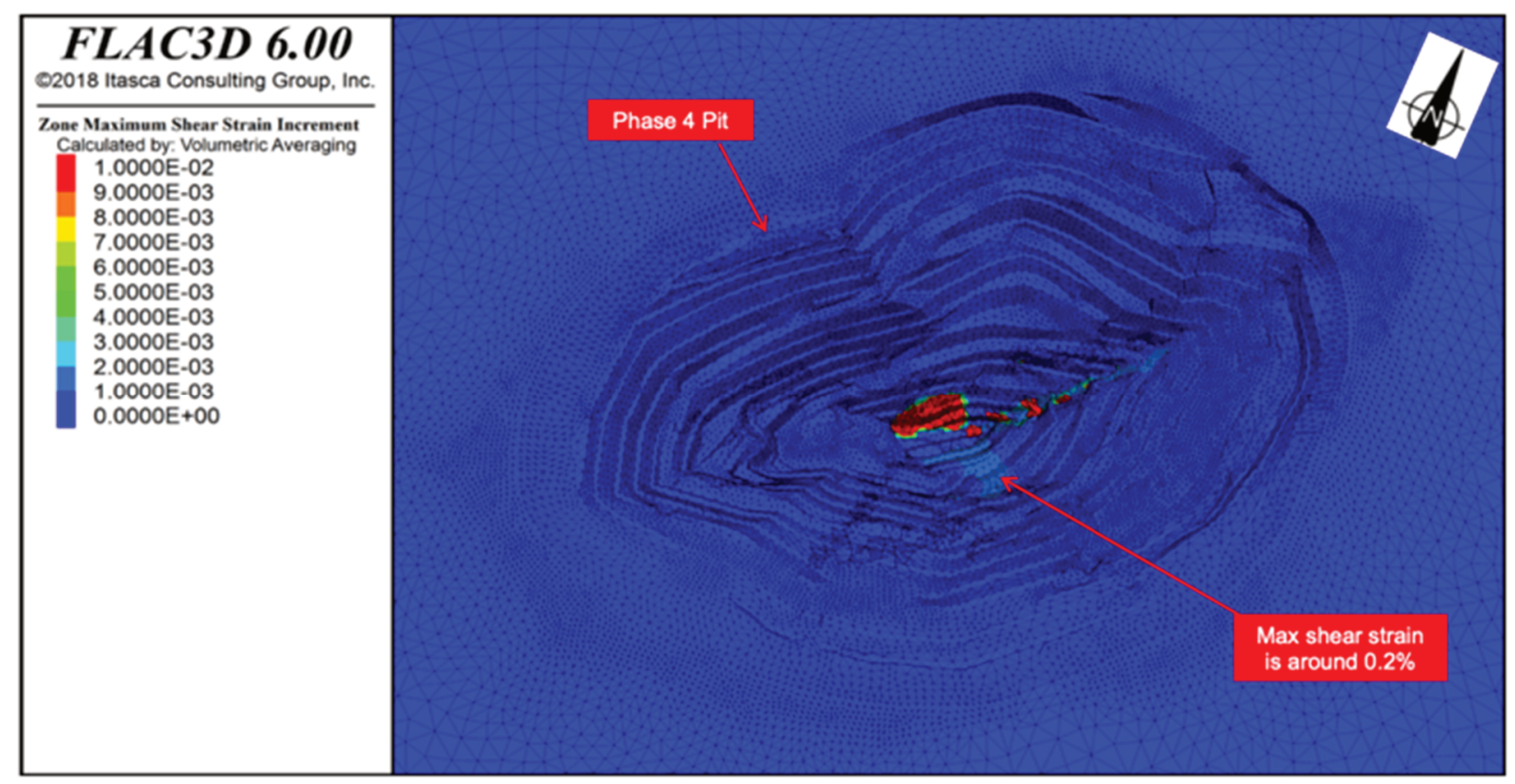

(b)

Figure 9 Predicted total displacement (a), and maximum shear strain (b), after Year 9 - Run 3 


\section{Conclusion}

The 3D numerical model has been developed to assess the geotechnical performance of Martha Phase 4 pit in response to the proposed Martha Underground. The model predicts a response to underground development that is aligned with the experience and previous performance of the Martha Pit slopes in terms of magnitude, location and distribution of movements. The base case (Run 1) simulating planned mining was found to result in relatively small displacements and strains with maximums of around $0.2 \mathrm{~m}$ and $1 \%$ respectively. Backfill also reduced localised areas of higher displacements and strains when compared to the no backfill case. The use of a significantly stiffer backfill to simulate CAF resulted in only a modest reduction in maximum displacement to around $0.08 \mathrm{~m}$ and maximum strains of around $0.2 \%$. Overall, the Martha Underground is predicted to result in relatively small displacements and strains and no global instability in the pit, provided the proposed stopes are backfilled. The maximum displacements would be around $0.2 \mathrm{~m}$ in the Martha Phase 4 pit walls based on simulated loose rockfill. The backfill stiffness used in this analysis is considered to be conservative. There is the potential for localised (bench scale) instabilities at the pit surface in some areas above the historical stoping. The modelling indicates that backfilling of historical unfilled stopes in the north wall of Martha Phase 4 pit would reduce the possibility of local crushing and or pillar/stope collapse potentially leading to local stability problems with the north wall of Martha Phase 4 pit. However, such backfilling has little to no effect on the overall displacements and strains on the pit walls.

The mathematical formulation behind the numerical code used for these analyses is based on behaviour of materials approaching either equilibrium or steady plastic deformations. As a result, the code is unable to reliably predict large post-failure deformations for situations which are far-off from an equilibrium state and for non-steady plastic deformations. The results presented here are likely to underestimate the post-failure displacements given that the non-steady plastic deformations are evident in some localised areas in the analysis. Consequently, displacement predictions have mainly been used to assess the deformation trend and to identify locations of relatively higher displacements and strains.

It is also noted that the analyses do not capture the ongoing creep movements that are known to exist at the mine. These movements are the consequence of ongoing relaxation, stope closure associated with the historical stopes and strain softening associated with time and weathering. At worst the magnitude of creep is expected to be similar to that experienced currently, this being up to $10 \mathrm{~mm}$ p.a., which is typical of open pits of this size. However, there are two positive elements of the planned Martha Underground that will assist with reducing the long-term creep of the rock mass:

- $30 \%$ of the existing unfilled historical stopes will be stabilised by filling with rockfill and approximately half of these are located in the upper levels immediately below the Martha Phase 4 pit.

- In addition, $30 \%$ of the planned mining will entail re-mining of historical stopes (remnant mining) comprising:

$\circ$ Mining from the top down.

- A very large proportion of these stopes are located immediately below the Martha Phase 4 pit.

- CAF or cemented rockfill will be used extensively in this mining.

These factors will result in a significant improvement in overall rock mass conditions in the zone underlying the Martha Phase 4 pit. This will have two positive impacts on Martha Phase 4 pit, firstly by improving pit stability conditions in both in the short and long-term and secondly by reducing any impacts of the Martha Underground mining in general.

\section{References}

AMC Consultants Pty Ltd. 2007, Site Visit Notes January 2007, unpublished consultant notes of Favona Underground Mine for Newmont Waihi Gold, dated March 2007.

Itasca Consulting Group, Inc. 2019, FLAC2D, version 6.00, computer software, Itasca Consulting Group, Inc., Minneapolis. 
Pells Sullivan Meynink Pty Ltd. 2003, 2002-2003 Geotechnical Investigations Waihi Vol. 1 Text, Plates \& Figures, Unpublished consultant report for Newmont Waihi Operations, Report Reference PSM125.R28, dated July 2003.

Pells Sullivan Meynink Pty Ltd. 2005a, Risk Assessment Pumphouse, unpublished consultant report for Newmont Waihi Operations, Report Reference PSM125.R33, dated April 2005.

Pells Sullivan Meynink Pty Ltd. 2005b, Geotechnical Review and Update 2004, unpublished consultant report for Newmont Waihi Operations, Report Reference PSM125.R31, dated January 2005.

Pells Sullivan Meynink Pty Ltd. 2006, Report on Pit Closure Studies, unpublished consultant report for Newmont Waihi Operations, Report Reference PSM125.R34, dated April 2006.

Pells Sullivan Meynink Pty Ltd. 2009a, Site Visit Report February 2009, unpublished consultant report for Newmont Waihi Operations, Report Reference PSM125.L105, dated February 2009.

Pells Sullivan Meynink Pty Ltd. 2009b, South Stability Cutback - Stability Update No. 2, unpublished consultant report for Newmont Waihi Operations, Report Reference PSM125.L106, dated March 2009. 